\title{
Citra Indonesia dalam Film dan Serial Televisi Hollywood
}

\author{
Herman Felani, S.S., M.A. \\ Program Studi Ilmu Komunikasi, Fakultas Psikologi dan Ilmu Sosial Budaya, \\ Universitas Islam Indonesia, herman.felani@uii.ac.id
}

\begin{abstract}
Abstrak
Penelitian ini bertujuan untuk membahas citra Indonesia dalam film dan serial televisi Hollywood. Penelitian ini adalah penelitian kualitatif dengan menggunakan pendekatan poskolonialisme yang berdasarkan pada teori orientalisme dari Edward Said. Berdasarkan temuan penelitian ini, Indonesia digambarkan sebagai negara yang aneh, kacau, dan tertinggal, sarang penjahat, tempat yang eksotis, terpencil, mistis dan misterius, dan pusat teroris. Munculnya citra tersebut disebabkan oleh kurangnya pengetahuan orang Amerika tentang Indonesia yang disebabkan oleh distorsi media massa.
\end{abstract}

Keyword : citra, Indonesia, film, serial televisi, Hollywood

\begin{abstract}
This research aims to discuss about the image of Indonesia in Hollywood Movies and TV Series. This research is a qualitative research using the post colonialism approach based on orientalism theory of Edward Said. Based on the findings of this research, the image of Indonesia in Hollywood movies and TV series is strange, messy, and left behind country, mystical and mysterious, isolated, place for criminals, and center of terrorists. This image is created because Americans are lack of knowledge about Indonesia caused by distortion of media and ignorance of Americans to view Indonesia in an objective manner.
\end{abstract}

Keyword : Image, Indonesia, film, TV series, Hollywood

\section{Pendahuluan.}

Indonesia merupakan salah satu negara pengkonsumsi Film terbesar di dunia. Di Nusantara, film masuk sejak era penjajahan Belanda dan diputar di layar bioskop. Ruffin (2016) menyatakan bahwa film pertama kali diputar di Nusantara pada tahun 1896. Berbagai catatan menunjukkan bahwa film yang paling banyak ditonton masyarakat Indonesia sejak saat itu hingga sekarang adalah filmfilm yang diimpor dari Amerika. Data dari MPAA (Motion Picture Association of America) bahkan menunjukkan di Tahun 2014 Indonesia menjadi negara ke 6 penyumbang penghasilan dalam industri film Hollywood. Sedangkan pada tahun 2015 Indonesia berada di urutan ke 16 dari 20 negara yang menyumbangkan penghasilan terbesar dalam industri hiburan Amerika untuk pasar film box office internasional dengan penghasilan sebesar 0,3 milyar dolar Amerika untuk tahun 2015 (MPAA, 2015). Jumlah ini setara dengan Argentina, Belanda, Taiwan, dan Hongkong. Hal ini menunjukkan bahwa film-film Amerika sangat digemari penonton Indonesia dan memberikan pemasukan yang besar sebagai sebuah bisnis hiburan. Fenomena ini menunjukkan bahwa hampir semua film Box Office di Amerika akan menjadi film 
laris pula di bioskop Indonesia. Penonton Indonesia sudah terbiasa dengan tontonan dari Amerika dan menjadikan film-film Amerika sebagai favorit. Hingga saat ini terdapat bioskop di 65 kota di Indonesia (Jakpat, 2015). Sebagian besar film yang diputar di bioskop Indonesia saat ini adalah film Hollywood.

Selain menjadi sasaran pasar bagi film-film Hollywood, Indonesia saat ini juga menjadi sasaran Hollywood sebagai lokasi pengambilan gambar. Diantaranya adalah The Fall (2006) karya Tarsem Singh yang mengambil lokasi di Ubud, Bali. Film lain adalah Eat, Pray, Love (2010) yang dibintangi oleh aktor dan aktris terkenal Hollywood Julia Roberts dan Javier Bardem yang juga mengambil lokasi di Ubud dan Gunung Kawi, Tampaksiring, Bali. Film ketiga adalah Amphibious (2010) yang mengambil tempat di Kelapa Gading \& Pantai Anyer, Jakarta, dan Batam. Pengambilan lokasi ini menunjukkan bahwa para pembuat film Hollywood memiliki ketertarikan pada Indonesia karena pertimbangan pasar atau pertimbangan strategis lainnya.

Selain penggunaan lokasi, beberapa film box office Hollywood juga menggunakan aktor dan aktris dari Indonesia. Misalnya data dari Internet Movie Data Base (IMDB) menunjukkan beberapa nama pemain dari Indonesia dalam film Hollywood. Yang pertama adalah Cinta Laura yang bermain di Film The Philosopers (2013) yang kemudian berganti judul menjadi After the Dark . Bintang lainnya adalah artis senior Christine Hakim yang mendapatkan kesempatan untuk bermain dalam film Eat, Pray, Love bersama seniman asli Bali Ketut Liyer. Bintang Indonesia ketiga yang bermain dalam film Hollywood adalah Joe Taslim yang bermain di Fast and Furious 6, bersama Vin diesel dan Paul Walker. Terpilihnya Joe di film ini karena perannya di film The Raid karya sutradara Gareth Evans. Joe juga direncanakan terlibat di film terbaru Yaitu Star Trek Beyond yang rencananya akan dirilis di Juli 2016. Bintang keempat adalah Iko Uwais yang mendapat peran di Film Star Wars terbaru yaitu Star Wars: The Force Awaken (2015). Di film Star Wars ini, Iko berperan sebagai tokoh antagonis Razoo Qin-Fee, anggota Kanjiklub. Mesti cuma mendapat adegan beberapa menit saja, Iko uwais ikut terlibat di Film arahan JJ Abraham ini.

Selain itu data dari IMDB juga mencatat beberapa film Hollywood yang menyingung atau menggunakan Indonesia dalam filmnya. Beberapa diantaranya adalah The Years of Living Dangerously (1982). Film yang dibintangi Mel Gibson ini berkisah tentang keadaan Indonesia di masa kejatuhan Presiden Soekarno. Selain itu, "Jakarta" disebut dalam film Tom Cruise, Mission: Impossible Rogue Nation. Ini terjadi saat adegan dimana agen IMF Ethan Hunt menjelaskan kepada Benji Dunn tentang sindikat yang sedang diburunya, dan disinilah ia menyebut Jakarta. Dalam film animasi laris dari Pixar, Minions, beberapa minion seperti Bob mengucapkan bahasa Indonesia seperti "terima kasih". Selain itu, dalam film Anaconda: The Hunt for the Blood Orchid (2004), Indonesia, lebih tepatnya Borneo atau Kalimantan disebut sebagai ujung dunia dimana anggrek langka yang mereka cari berada. Dalam film laga yang dibintangi Bruce Wilis, Die Hard (1988), "Sumatera" atau "Jawa" disebut-sebut sebagai lokasi tujuan pembuatan kilang minyak oleh karakter pengusaha pemilik Nakatomi Plaza. Dalam Film Italian Job (2003), disebutkan bahwa batangan emas yang diperebutkan berasal dari tambang di Indonesia, bahkan batangan emas tersebut bergambar Penari Bali. Di film Jumanji (1995) disebutkan bahwa permainan Jumanji berasal dari Kalimantan, Kirsten Dunst bahkan sempat berkata kalau Jumanji, "sounds like Indonesian name". Dalam adegan lain, Kirsten juga menjelaskan kalau Robin Williams adalah 
pamannya yang berasal dari Indonesia. Sedangkan dalam Film King Kong (2005), Indonesia disebut namun digambarkan sebagai daerah antah berantah yang primitif dan dihuni makhluk bernama King Kong.

Selain film, beberapa serial televisi Amerika juga menyinggung Indonesia dalam beberapa dialognya. Yang pertama adalah serial The West Wing (1999), serial TV yang berlatar Gedung Putih Amerika. Salah satu episodenya menceritakan tentang kesibukan Gedung Putih saat menerima tamu negara yaitu Presiden dari Indonesia. Serial TV kedua adalah serial House yang yang cukup populer pada tahun 2004. Film ini dibintangi oleh Hugh Laurie sebagai dr. House, seorang dokter di klinik yang memecahkan berbagai penyakit langka. Dalam cerita ada satu adegan dimana dr. House sedang mengobati seorang anak kecil yang sedang sakit parah. Tiba-tiba si dokter itu berkata, "Seorang anak yang sakit sampai parah begini, tinggalnya pasti di Indonesia”.

Dari data dan fakta di atas dapat diduga bahwa Hollywood menaruh perhatian terhadap Indonesia dan memiliki pandangan tersendiri mengenai Indonesia. Hal ini ditampilkan dalam Film dan Serial Televisi di Hollywood sebagai budaya populer yang dikonsumsi secara massal oleh penonton dari seluruh dunia. Holman (1983) menyatakan bahwa minat Hollywood terhadap Indonesia untuk kepentingan industri sudah ada sejak masa kolonial dan dilakukan secara terorgansisir.

Melihat berbagai respon positif maupun negatif dari Hollywood terhadap Indonesia, menjadi menarik untuk meneliti tentang "Citra Indonesia di dalam Budaya Populer Hollywood khususnya Film dan serial televisi. Berdasarkan latar belakang di atas, penelitian ini mengajukan dua pertanyaan penelitian sebagai berikut: 1) Bagaimana citra Indonesia dalam Film dan Serial Televisi
Hollywood, 2) Mengapa citra mengenai Indonesia tersebut muncul dari Hollywood.

\section{Metode Penelitian}

Elsaesser dan Buckland (2002) menyatakan bahwa dalam mempelajari Film Amerika kontemporer, perlu digunakan teori khusus untuk konteks yang tepat, daripada menggunakan teori yang sama dalam semua konteks. Penelitian kualitatif ini melakukan analisis terhadap film-film Hollywood dan Serial Televisi yang berkaitan dengan Indonesia dengan menggunakan pendekatan postkolonialisme yang berdasarkan pada teori orientalisme dari Edward Said. Said (1980) menyatakan bahwa orientalisme adalah suatu cara untuk memahami dunia Timur berdasarkan tempatnya yang khusus dalam pengalaman manusia Barat Eropa. Dengan basis teori ini, maka filmfilm dan serial televisi yang dibahas dalam penelitian ini selalu dikaitkan dengan persepsi barat mengenai bangsa di timur termasuk Indonesia. Metode analisis yang digunakan adalah metode analisis film dari Aumont dan Marie (1988) yang menyatakan bahwa analisis film merupakan salah satu cara dalam teori film atau film studies untuk mengungkapkan makna. Salah satu cara paling umum untuk menganalisa film adalah dengan analisis shot-by-shot, karena bagian ini yang paling bisa mencakup aspek-aspek terdetail dalam film. Data film dikumpulkan dari Internet Movie Data Base (www.imdb.com) dengan menggunakan kata kunci yang sesuai dengan pertanyaan penelitian. 
Analisis dan Pembahasan

Citra Indonesia dalam Film dan

\section{Serial Televisi Hollywood}

Dari temuan penelitian, Indonesia digambarkan oleh Film dan Serial Televisi Hollywood memiliki citra sebagai berikut:

\section{Indonesia adalah Negara yang Aneh dan Kacau}

Di film Lethal Weapon 4 1998, Indonesia digambarkan sebagai negara yang "selalu membuat kekacauan". Dalam salah satu adegannya, Danny Glover memaki-maki dengan mimik khasnya, "Kapal bodoh ini dibuat oleh seorang yang berasal dari Indonesia”. Dalam film tersebut, terdapat adegan dimana ada imigran China yang diselundupkan menggunakan kapal yang diatasnamakan sebuah perusahan di Indonesia. Dialog ini muncul ketika Mel Gibson berbicara di markas sebelum menyerbu Uncle Benny. Dalam dialog mereka, Indonesia digambarkan sebagai negara yang "selalu membuat kacau".

Dalam Film Stranger With Candy, terdapat dialog sebagai berikut ini:

Perempuan: Where are you from?

Laki-laki: Jakarta, indonesia

Perempuan: What's your name?

Laki-laki: Megawati Soekarnoputri

Perempuan: (sambil melihat bingung kepada laki-laki itu)

Laki-laki: What? It's a common name in Indonesia.

Dialog tersebut mengesankan bahwa orang Indonesia aneh dan bahkan nama presiden Indonesia kelimapun digunakan sebagai nama laki-laki.

Dalam The Sweetest Thing, sebuah film drama psikologi, Cameron Diaz mengatakan "Kalian membuat kacau saja seperti di Indonesia." Lalu Christina Applegate masuk ke apartemen dan melihat apartemennya berantakan, dia bilang "this place is a mess like Indonesia." Pernyataan dalam film ini cukup menarik karena film drama ini sebenarnya tidak ada kaitan cerita sama sekali dengan Indonesia namun menyebut Indonesia beberapa kali sebagai tempat yang kacau.

Dalam Taladega Night: The Ballad Of Ricky Bobby, sebuah film komedi dari Will Ferell, terdapat adegan supporter anak-anak yang berteriak kepada musuhnya dengan kata-kata "send that freak back to Indonesia!”. Padahal orang yang dimaksud aneh atau freak itu sendiri adalah orang Prancis.

Dalam film "Children of Men", digambarkan ada berita televisi yang menunjukkan Jakarta mengalami kehancuran. Dalam film 28 Days later, di awal film, ada adegan para monyet di laboratorium yang sedang disuguhi adegan kekerasan. Salah satunya adalah adegan dari kerusuhan Mei 98 di Indonesia. Hal ini mengindikasikan bahwa Indonesia penuh dengan kekerasan dan kekacauan.

Dalam Film Jumanji, terdapat permainan berbahaya yang dimainkan oleh Robin Williams. Pada salah satu adegannya diceritakan bahwa ia kembali ke dunia nyata dengan berpakaian compang-camping dan bertingkah seperti orang sakit jiwa yang membahayakan lingkungannya. Kirsten Dunst berkata kepada polisi bahwa Williams adalah pamannya yang berasal dari Indonesia, sehingga polisi tidak jadi menangkapnya. Jumanji itu sendiri diceritakan permainan yang berasal dari Kalimantan, yang ditimpali Kirsten Dunst dengan berkata "Sounds like Indonesian name". 


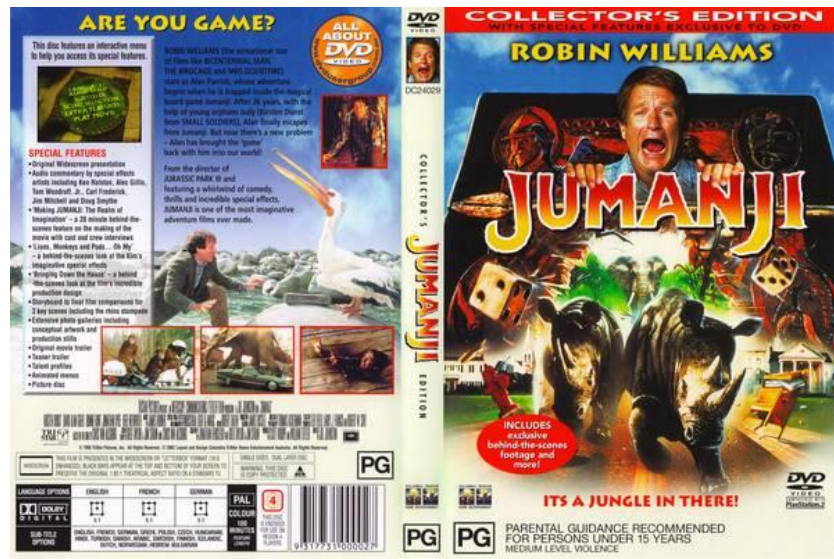

Gambar 1. Sampul Film Jumanji

Sumber: www.imdb.com

Selain itu, seorang gadis berbicara bahasa Indonesia di sebuah film Hollywood berjudul Bob Funk (2009). Dia berkata pada seorang lelaki yang menggodanya "Orang bule, saya minta maaf saya tidak mengerti kamu ngomong bahasa apa. Saya hanya bisa bahasa Indonesia, tidak bisa bahasa Inggris seperti kamu". Gadis tersebut kemudian dipandang aneh dan lelaki tersebutpun membatalkan niatnya menggoda sang gadis.

Dari bebeberapa contoh film tersebut dapat dilihat bahwa Indonesia dan orang Indonesia dipandang sebagai negara dan orang yang aneh, asing, dan penuh kekacauan. Hal ini menunjukkan pandangan dari pada pembuat film yang menggunakan Indonesia sebagai bagian dari cerita atau dengan memakai orang Indonesia sebagai pemain.

\section{Indonesia sebagai negara tertinggal}

Citra lain yang muncul tentang Indonesia dalam film Holywood adalah Indonesia sebagai negara tertinggal. Hal ini dapat dilihat pada contoh beberapa film berikut ini. Yang pertama adalah Film The Year of Living Dangerously (1982) ini berkisah tentang seorang wartawan yang dikirim untuk bertugas di Jakarta pada tahun 1965-1966. Saat itu, Indonesia yang dipimpin oleh Presiden Soekarno sedang mengalami krisis politik dan ekonomi. Tak heran, situasi Jakarta digambarkan sangat kacau, lengkap dengan embel-embel penduduk yang merana karena kelaparan. Film ini dibintangi Mel Gibson dan Sigourney Weaver dengan lokasi syuting di Filipina, karena tidak diijinkan pemerintah di Jakarta. Akibatnya meski ada beberapa dialog menggunakan Bahasa Indonesia, namun karena aktornya adalah orang Filipina, maka ucapannya terdengar aneh di telinga. Adegan yang paling terkenal adalah sewaktu rekan Mel Gibson, Billy menggantungkan spanduk di Hotel Indonesia di Jakarta dengan tulisan "Soekarno, Feed Your People!".

Permasalahan hukum di Indonesia juga dimunculkan dalam Film Hollywood. Dalam In the God's Hand (1998) diceritakan tentang dua pemuda berkebangsaan Amerika yang tergila-gila dengan olahraga surfing (selancar). Keduanya bertekad untuk menjajal semua jenis ombak lautan di penjuru dunia. Saat adegan di Pulau Lombok keduanya ditangkap polisi karena melanggar aturan. Salah satu dari kedua pemuda itu lantas menyuap polisi dengan mengajak salaman dan menempelkan selembar uang ke 
tangan polisi. Alhasil mereka berdua lolos. Hal ini menunjukkan bahwa dalam film tersebut aparat hukum Indonesia digambarkan mudah disuap

\section{Looking For Jackie Chan (2009)} merupakan film yang menceritakan seorang anak Indonesia keturunan China (Tionghoa) yang mengidolakan super bintang Jackie Chan. Anak ini digambarkan dengan sikap yang dianggap khas sebagai orang Indonesia, di antaranya sering melanggar aturan dan tidak disiplin. Misalnya ketika adegan si anak menerobos brigade satpam dan melarikan diri rumah. Hal ini juga menunjukkan bahwa seakanakan perilaku orang Indonesia cenderung tidak taat hukum dan tidak disiplin.
Indonesia adalah Sarang penjahat

Beberapa film Hollywood terutama

film laga menggunakan Indonesia sebagai bagian cerita dengan citra negatif yaitu sebagai sarang penjahat seperti Film Blackhat. Film ini tidak hanya menyebut Indonesia, tapi juga melakukan pengambilan gambar di beberapa lokasi di Indonesia yaitu Lapangan Banteng, sekitar Pelabuhan Sunda Kelapa, Tanah Abang, Apotek Melawai dan Lapangan Banteng. Dalam film ini diceritakan bahwa ada sebuah kasus peretasan berat yang dilakukan oleh seorang hacker jenius yang lari ke Indonesia.

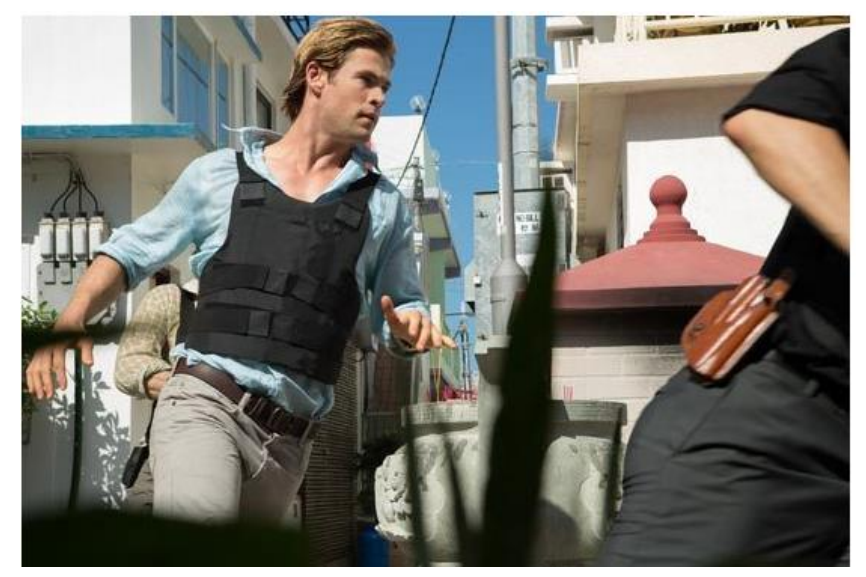

Gambar 2. Adegan dalam Film Blackhat yang berlokasi di Indonesia Sumber: www.imdb.com

Dalam serial televisi Boston Public (2000), ada adegan dimana saat salah satu murid sekolah disana ternyata imigran gelap dari Indonesia bernama Sri. Dalam film itu Tania Gunadi, aktri asal Indonesia berperan sebagai orang Indonesia bernama Sri Sumarto dalam tiga episode drama seri FOX tersebut. Tokoh Indonesia tersebut berwajah oriental, termasuk sang ayah. Ketika sang guru datang ke rumah persembunyian mereka, Sri membuka pintunya dan bertanya menggunakan bahasa Indonesia dengan kalimat "siapa itu?"

Pada salah satu episode serial televisi CSI: Miami (2002), ketika ada banyak mayat orang dirantai di dasar laut, Letnan Cane berdiskusi dengan rekan sejawatnya dan berkata "Apa yang terjadi disini? Ini bukan cara perompak Indonesia maupun Mafia biasa”.Dalam Film The Devil's Advocate (1997), Al Pacino sempat menyebut soal perdagangan senjata di Jakarta. 
Dalam film The Saint (1997) yang dibintangi Val Kilmer, ada adegan ketika pemeran utamanya menerima e-mail dari laptop. Dalam e-mail tersebut, terdapat tulisan Bali Indonesia dan Jakarta. Film Point Break (1991) yang dibintangi oleh Keanu Reeves bercerita tentang agent CIA yang mengejar penjahat yang berprofesi juga sebagai seorang surfer sampai ke Sumatra dan Bali. Pada akhirnya penjahat tersebut tertangkap di Australia ketika akan surfing pada saat terjadi badai.

Dalam film yang thriller psikologi The Silence Of The Lambs (1991) yang dibintangi Jodie Foster ini ada adegan dimana di sweater orang yang diculik kanibal bertuliskan "Made In Indonesia" yang menunjukkan Indonesia sebagai negara yang memiliki banyak kasus penculikan.

Dari beberapa uraian di atas dapat dilihat bahwa film-film Hollywood banyak yang mencitrakan Indonesia dan orang Indonesia dengan kejahatan. Indonesia bisa digunakan lokasi penjahat melarikan diri, asal dari penjahat tersebut atau tempat berlangsungnya kejahatan.

\section{Indonesia tempat yang eksotis, terpencil, dan misterius}

Film Anaconda: The Hunt for the Blood Orchid (2004) menggambarkan Indonesia sebagai tempat yang terpencil dan misterius. Di film ini, Indonesia, lebih tepatnya Borneo atau Kalimantan disebut sebagai ujung dunia dimana anggrek langka yang mereka cari, berada. Sekuel Anaconda ini bercerita tentang sekelompok ilmuwan yang melakukan ekspedisi untuk mencari anggrek berdarah yang langka yang dipercaya bisa membuat awet muda. Anggrek tersebut berada di suatu lokasi yang sangat terpencil yang dipenuhi oleh sejumlah flora dan fauna yang aneh-aneh, dan tentu saja si Anacondanya sendiri yang jumlah dan ukurannya sangat tidak biasa. Disebutkan bahwa ujung dunia tersebut adalah Borneo
(Kalimantan), tapi kondisi flora dan faunanya malah menggambarkan Hutan Amazon. Kemudian diceritakan bahwa mereka menyusuri Sungai Mandranang dari Kota Baru (padahal tidak ada Sungai Mandranang) dan Kota Baru sebenarnya di Pulau Laut Kalsel bukan di Kalimantan daratan. Film ini juga menggunakan lagu rap dari Iwa $\mathrm{K}$ yang berjudul "Nombok Donk”. Film ini menunjukkan banyak ketidakakuratan data mengenai Indonesia demi menunjukkan kesan dan citra eksotis dan terpencil dari Indonesia.

The Island Of Dr. Moreau (1996) adalah film tentang obsesi seorang ilmuwan gila untuk menggabungkan manusia dan hewan menjadi suatu spesies baru. Lokasi penelitiannya berada di suatu pulau terpencil di kawasan Indonesia Timur. Untuk mempertegas posisi Indonesia dalam film ini, Sutradara kawakan John Frankenheimer bahkan menggunakan kapal bernama "Ombak Penari” dan si awak kapal ketika akan sampai di pulau itu ada yang berbicara dengan menggunakan Bahasa Indonesia. Padahal sebenarnya nama kapal itu terbalik. Dalam versi novel yang ditulis H.G. Wells, kapal yang ada di film ini bernama Ipencacuanha. Di versi film, nama kapalnya berubah menjadi Ombak Penari yang diambil dari kata Wave Dancer. Padahal disesuaikan dengan tata bahasa, seharusnya terjemahannya adalah Penari Ombak.

Dalam film The Italian Job (2003) disebutkan bahwa batangan emas yang diperebutkan berasal dari tambang di Indonesia, bahkan batangan emas tersebut bergambar Penari Bali. Emas di film ini ceritanya berasal dari tambang emas di Indonesia.Di film tidak disebutkan secara spesifik. Akan tetapi pada trailernya, narator film menyebut kalau emas ini diambil dari tambang di Indonesia.

Dalam Film Friday The 13th terdapat adegan saat yang menampilkan gudang dengan topeng leak dari Bali dan 
dalam film Spiderman 2, terdapat adegan yang menampilkan topeng barong dari Bali di kamar Orsborne sewaktu dia mengira topeng tersebut sebagai asal keluarnya suara Green Goblin. Selain itu dalam film Alice In Wonderland (2010), Alice menyebutkan Sumatra dan Borneo sambil membuka peta Indonesia, tepatnya pulau Sumatera.

Dalam King Kong (2005) yang dibintangi oleh Adrien Brody, Naomi Watts, dan Jack Black, Indonesia digambarkan sebagai suatu negeri antah berantah yang primitif dan terbelakang, yang berada nun jauh di sana, yang dihuni oleh binatang langka berjuluk King Kong dan penduduk pribumi yang sangat barbar, di Pulau Tengkorak (Skull Island), yang dikisahkan di sebelah barat Sumatera. Kapalnya juga bernama "Soerabaja", tertulis di buritan kapal. Sedangkan syuting mengenai pulau itu dibuat di wilayah Thailand Selatan dan di Lyall Bay, Wellington. Padahal kalau melihat peta yang tercantum di film King Kong itu, Pulau Tengkorak itu tak lain adalah Pulau Nias.

Indonesia juga disinggung dalam Film Braindead (1992) yang dibuat oleh Peter Jackson sebelum terkenal. Braindead a.k.a Dead Alive adalah sebuah horor komedi tentang virus mematikan yang berasal dari kera Sumatra. Selain itu dalam Legends of the Fall (1994), Brad Pitt diceritakan merantau ke berbagai tempat termasuk Sumatera dan Jawa. Bahkan dia mendapat kalung gigi babi hutan dari Jawa.

Salah satu film klasik menggambarkan tentang letusan gunung Krakatau dengan judul Krakatoa: East Of Java (1969). Film ini memiliki kesalahan judul karena Krakatau berlokasi di Pulau Jawa bagian barat, bukan di sebelah timur Pulau Jawa.

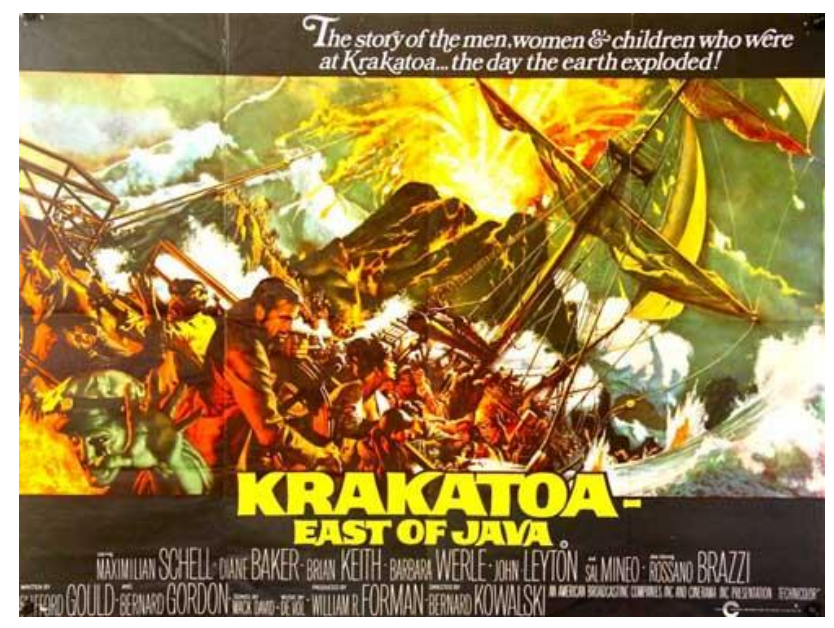

Gambar 3 . Poster Film Krakatoa: East of Java Sumber: www.imdb.com

Data di atas menunjukkan bahwa Indonesia diidentikkan dengan tempat yang eksotis, penuh dengan spesies aneh, terpencil, dan mistis. Namun penggambarannya cenderung tidak akurat baik dari secara geografis, historis, maupun dari aspek antropologis.

\section{Indonesia sebagai Pusat terorisme}

Film Java Heat berusaha mewujudkan kolaborasi antara budaya Barat dan Timur, dengan memberikan cara pandang lain tentang Islam di Indonesia yang terpengaruh budaya Jawa. Film yang 
dibintangi aktor Hollywood, Mickey

Rourke dan Kellan Lutz ini mengambil proses shooting di Candi Borobudur dan sejumlah spot di Yogyakarta.

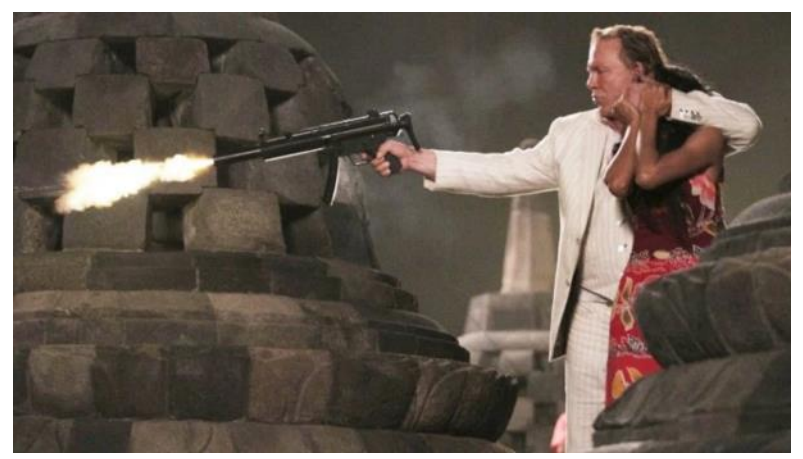

Gambar 4. Film Java Heat yang berlokasi di Candi Borobudur Sumber: www.imdb.com

Dalam Java Heat, ada banyak adegan kejar-kejaran, perkelahian dan tembak menembak. Film ini menceritakan tentang pencurian dan pembunuhan di daerah Keraton Yogyakarta oleh kawanan sindikat yang salah satunya meledakkan diri di tempat itu saat ada acara di dalam keraton.

Serial Televisi Alias (Season 1, 4, dan 5), pernah mengambil gambar salah satu episodenya (21) di Bali, di tengah kota Denpasar. Yang menandakan tenpat itu Bali adalah adanya bangunan pura dan perempuan yang membawa buah di kepala. Ceritanya Sidney (Jen Garner) sedang menyamar menjadi orang Bali (sebagai laskar) yang lalu bertemu Shark yang sedang mencari parfum. Kemudian di Season 4 atau 5 juga disebut ada Jakarta Project. Dan di episode lain ada juga cerita tentang kedutaan Indonesia di bom. Dalam episode itu diceritakan Indonesia punya senjata kimia berbahaya.

Dalam Serial TV, Commander In Chief (2006), salah satu episodenya menceritakan tentang Presiden Amerika Serikat bernama Geena Davis (pemeran Mackenzie Allen, presiden wanita AS pertama) membantu Presiden Indonesia untuk memerintahkan pasukan TNI melawan teroris yang bermukim di perbatasan Kalimantan-Serawak. Pertempuran terjadi di bawah pimpinan seorang Letnan Jenderal TNI yang membawahi pasukan elit dari TNI (yang disebut "ranger") dan juga elit AS untuk membantu menumpas teroris yang juga memprovokasi untuk melakukan gerakan separatis, dimana gerombolan ini mencoba menyeberang perbatasan di KalimantanSerawak.

Terjadi perdebatan sengit di dewan senat AS dalam pengiriman pasukan elit ini, bahkan ditolak karena Senat beranggapan Presiden Indonesia mampu menyelesaikan masalah ini tanpa bantuan AS. Akan tetapi berbagai kepentingan seperti para ilmuwan AS yang ikut disandera oleh teroris menjadi agenda khusus pemerintah AS yang diam-diam mengirim pasukan AS ini ke Indonesia dengan persetujuan presiden Indonesia. Selain itu, ada agen mata-mata wanita yang dikirim untuk membantu TNI dan grup pasukan elit AS memberikan info detail untuk menumpas teroris tersebut sangat fasih berbahasa Indonesia. Bahkan pada saat pertempuran sengit berlangsung banyak terjadi dialog bahasa Indonesia yang cukup kental dalam serial ini.

Dalam Film The Kingdom (2007), diceritakan tentang aksi terorisme di Arab 
Saudi dan dikatakan bahwa ada ancaman tentang aliran dana group radikal yang mengalir ke Jakarta. Dan dalam film Proof of Life (2000) bercerita tentang agen khusus pembebasan sandera, salah satu target operasinya adalah di Indonesia, yaitu di Jakarta.

Serial TV Sleeper Cell (2005-2007) bercerita tentang Darwyn Al-Sayeed, seorang muslim Afrika-Amerika yang bekerja sebagai agen FBI. Tugas Darwyn adalah mengusut kasus terorisme yang dilakukan organisasi teroris pimpinan Faris Al-Farik. Diceritakan, dalam episode Target dan Scholar, Darwyn berurusan dengan tokoh mahasiswa Indonesia bernama Eddy Pangetsu (Jeff Mallare). Eddy digambarkan sebagai ahli biologi kimia yang direkrut Faris Al-Farik untuk membuat virus anthrax yang disebar di Amerika. Menariknya, salah satu adegan menggambarkan Faris menuduh Eddy menyelundupkan virus tersebut ke Indonesia untuk dikirimkan ke pamannya, seorang gangster lokal. Dalam episode ini orang Indonesia digambarkan cerdas, tapi gemar berperang. Sleeper Cell yang punya tagline "Friends. Neighbours. Husbands. Terrorists" ini ternyata cukup mendapat perhatian di negara asalnya. Tahun 2006 serial ini dinominasikan mendapat Emmy Awards untuk kategori Outstanding Miniseries, serta Golden Globe untuk Best Miniseries. Namun, Sleeper Cell tidak memenangkan nominasi apapun dan Jeff Mallare si pemeran Eddy Pangetsu juga tidak masuk nominasi. Jadi dalam film ini, Indonesia digambarkan sebagai sarang teroris.

Dalam film Smallville (Serial TV, season 2) (2003) yang merupakan seri drama AS menampilkan watak Clark Kent (Superman) sewaktu zaman remajanya di pekan Smallville, Kansas dan pernah ditayangkan di stasiun televisi SCTV. Dalam film ini kekasih Lana, Whitney, diceritakan mati di Aceh waktu ketika mengikuti wajib militer di Marinir. Saat sedang berpatroli, kendaraan yang membawa Whitney dan peletonnya dibombardir, dihujani ledakan bertubitubi. Adegannya mirip kondisi perang di Irak. Anehnya Aceh digambarkan bagaikan gurun-gurun bebatuan dan disisi lain, digambarkan tentara Amerika yang membantu melawan Gerakan Aceh Merdeka (GAM) di Aceh, digambarkan di lokasi berawa-rawa dan dtuliskan lokasinya di Aceh, Indonesia

Serial TV The Agency (2001-2003) adalah cerita fiktif tentang sepak terjang agen CIA dalam tugasnya. Namun meskipun fiktif, ceritanya dibuat serealistis mungkin sesuai kondisi lapangan. Salah satu kisahnya adalah tentang upaya CIA menggagalkan kudeta serorang gubernur di Kalimantan karena dianggap bisa mengancam aset dan keselamatan orang Amerika di Indonesia. Dalam film tersebut diceritakan gubernur Kalimantan itu bisa memobilisasi tentara dan juga diceritakan agen CIA menyusup ke indonesia. Disana diceritakan salah seorang wartawan bernama Diah adalah agen CIA, dan beberapa orang Indonesia lain yang tak mencolok, seperti tukang roti dan pengangguran ternyata adalah agen CIA.

The Unit (2006-2009) adalah serial televisi tentang kesatuan unit anti teroris dalam salah satu episodenya bersetting di Medan. Akan tetapi terdapat beberapa keganjilan seperti Kota Medan berplat nomor F dan Medan digambarkan sebagai kota yang sangat kumuh. Para pemberontak dalam film tersebut sangat fasih berbahasa Inggris. Mereka berbahasa Indonesia seperti orang asing yang baru belajar Bahasa Indonesia. Satu-satunya kalimat Indonesia yang fasih diucapkan adalah ketika mereka bicara dengan salah seorang operator mereka yang mirip orang Indonesia asli.

Berbagai film dan serial televisi Hollywood menggunakan Indonesia sebagai bagian cerita atau lokasi para teroris dunia. Hal ini menunjukkan bahwa 
Indonesia masih diidentikkan dengan sarang terorisme.

\section{Penyebab Munculnya Citra Negatif Indonesia dalam Film dan Serial Televisi Hollywood}

\section{Kurang pengetahuan orang Amerika tentang Indonesia}

Adanya penggambaran yang tidak tepat tentang Indonesia menunjukkan kurang pengetahuan orang Amerika khusus para pekerja di industri hiburan Hollywood tentang Indonesia. Misalnya film Krakatoa yang bercerita tentang letusan Gunung Krakatau justru menyebutkan kalau gunung tersebut berlokasi di timur Pulau Jawa. Contoh lain adalah keanehan dalam Film Anaconda: The Hunt for the Blood Orchid. Dalam film itu disebutkan bahwa ujung dunia tersebut adalah Borneo (Kalimantan), tapi kondisi flora dan faunanya malah menggambarkan Hutan Amazon. Kemudian diceritakan bahwa mereka menyusuri Sungai Mandranang dari Kota Baru (padahal tidak ada Sungai Mandranang) dan Kota Baru sebenarnya di Pulau Laut Kalimantan Selatan dan bukan di Kalimantan daratan. Selain itu, dalam Film Dunston Check-In (1996) diceritakan tokoh utamanya sedang berlibut ke Bali. Namun yang aneh adalah meskipun suasananya di Bali, lengkap dengan pantai dan pohon kelapa dan nuansa Bali lainnya, tetapi orang-orangnya semuanya memakai kimono dan berbahasa Jepang.

Beberapa ahli berargumen bahwa ada beberapa alasan mengapa Indonesia tidak banyak diketahui dunia asing dan diliput media internasional. Alasan pertama adalah situasi Indonesia yang tidak sesuai dengan minat atau isu yang menarik bagi media untuk dipromosikan. Indonesia bukanlah negara yang mengancam dominasi ekonomi Amerika seperti halnya China dan India. Indonesia juga bukan negara diktator yang menentang barat seperti Venezuela, Iran, dan Korea Utara, dan Indonesia bukanlah sisa musuh perang dingin seperti Rusia dan atau Kuba. Alasan kedua adalah, meskipun ekonomi Indonesia cukup besar, Indonesia hanya menduduki peringkat ke 27 untuk mitra dagang Amerika sehingga tidak banyak berita tentang Indonesia yang menarik bagi orang Amerika. Selain itu, sulit bagi orang asing untuk menulis laporan yang berkualitas tentang Indonesia karena tidak banyak orang yang bisa berbahasa Inggris di Indonesia, serta keragaman kebudayaan dan bahasa membuat sulit untuk orang asing berkomunikasi dan memahami Indonesia. Penerbangan langsung ke Indonesia juga sangat terbatas. Selain itu, jumlah orang Indonesia di dunia barat juga terbatas, sehingga pemahaman barat tentang Indonesia masih sangat terbatas.

Bukti-bukti tersebut menunjukkan bahwa para pekerja industri hiburan Hollywood yang memproduksi film-film tersebut tidak memiliki pengetahuan yang lengkap tentang Indonesia.

\section{Stereotip media massa di Amerika tentang Indonesia}

Media massa di Amerika sangat mempengaruhi bagaimana masyarakat Amerika memandang Indonesia. Cipto (2003) memberikan contoh bahwa media massa Amerika yang memainkan peranan penting dalam mengembangkan dengan cepat pendapat umum tentang pelanggaran hak asasi manusia di Timor Timur. The New York Times memuat editorial yang berjudul "The Tiananmen in East Timor", yang kemudian berita ini menyebabkan suhu politik Amerika Serikat memanas.

Cipto (2003) juga menilai bahwa media massa Amerika (The New York Times) meliput berita-berita sesuai dengan kebijakan Amerika tentang pelanggaran hak asasi manusia di Timor Timur. The New York Times memberikan dukungan 
terhadap sikap kritis Amerika terhadap Indonesia dengan melaporkan tindakantindakan tak manusiawi yang dilakukan polisi dan tentara Indonesia terhadap penduduk Timor Timur yang beragama Kristen. Merujuk pada hasil penelitian tersebut, media massa dapat bersikap mendukung atau bahkan mengkritisi kebijakan politik suatu negara.
Selain itu, ada juga beberapa media Amerika yang memuat berita negatif yang memandang Indonesia sebagai negara yang tertinggal dan primitif. Seperti dimuat dalam karikatur berikut ini.

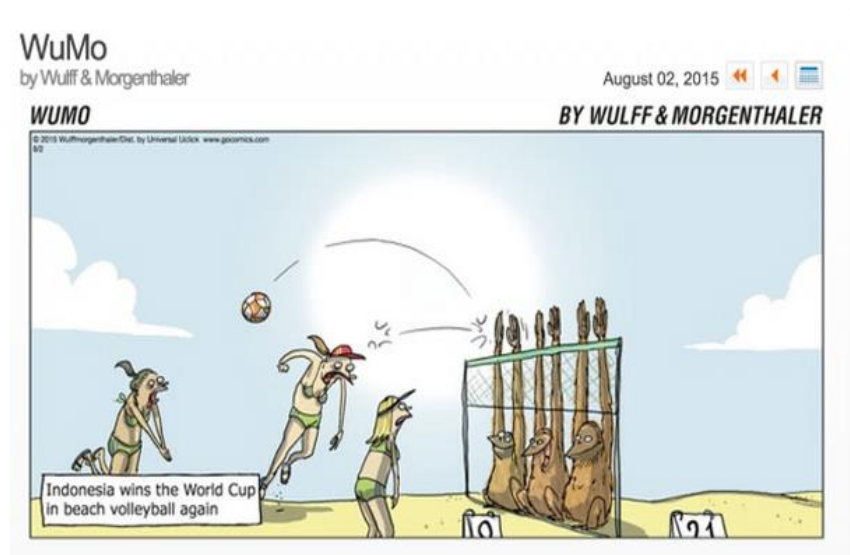

Gambar 5 Karikatur Amerika yang Melecehkan Indonesia

Dalam karikatur ini, Wulff dan Morgenthaler membuat karikatur yang menggambarkan kemenangan Indonesia dalam kejuaraan bola voli pantai dunia karena menggunakan atlit orang utan yang bertangan panjang. Pembuat komik yang terkenal dengan sebutan WuMo ini memiliki situs berisi komik dan ilustrasi lainnya dari Denmark. Komik-komik yang dimuat bernuansa satir. Pelanggan kartun buatan WuMo termasuk surat kabar berpengaruh the New York Times. Hal ini menunjukkan bahwa media kenamaan Amerika juga menunjukkan citra negatif tentang Indonesia.

Citra umum Indonesia dalam media adalah Bali dan orang-orangnya yang digambarkan sebagai surga, atau orang Aceh yang akan menghancurkan apa saja yang berbau barat. Selain itu, Jakarta tidak mendapatkan perhatian kecuali jika terjadi demonstrasi atau pemilihan umum. Timor Leste selalu menjadi headline dalam berita tahun 1998 hingga 2002 dan 2006 sampai 2007. Selain itu, stereotip yang muncul tentang Indonesia dalam media Amerika biasanya berkaitan dengan stabilitas politik, kurangnya transparansi, fundamentalisme agama, kekerasan terhadap orang asing. Selain itu berita tentang terorisme cukup tinggi dimunculkan dalam media massa Amerika. Bahkan beberapa situs seperti wikipedia memiliki entri khusus tentang tindak terorisme di Indonesia. Berikut ini merupakan tabel dari www.wikipedia.org. mengenai jumlah kejadian terorisme di Indonesia. 
Tabel 1: Jumlah Kejadian Terorisme di Indonesia

\begin{tabular}{|c|c|c|c|}
\hline \multirow[t]{2}{*}{ Tahun } & \multirow{2}{*}{\begin{tabular}{|l|} 
Jumlah \\
Insiden \\
\end{tabular}} & \multirow{2}{*}{$\begin{array}{c}\text { Korban } \\
\text { tewas }\end{array}$} & \multirow[t]{2}{*}{ Luka-luka } \\
\hline & & & \\
\hline 2016 & 19 & 22 & 35 \\
\hline 2015 & 28 & 19 & 17 \\
\hline 2014 & 33 & 19 & 30 \\
\hline 2013 & 32 & 23 & 16 \\
\hline 2012 & 39 & 15 & 20 \\
\hline 2011 & 21 & 20 & 70 \\
\hline 2010 & 4 & $\mathrm{O}$ & 6 \\
\hline 2009 & 19 & 15 & 62 \\
\hline 2008 & 13 & 0 & $\mathrm{O}$ \\
\hline 2007 & 2 & 0 & 1 \\
\hline 2006 & 10 & 6 & 6 \\
\hline 2005 & 15 & 66 & 171 \\
\hline 2004 & 17 & 42 & 238 \\
\hline 2003 & 18 & 26 & 166 \\
\hline 2002 & 43 & 246 & 535 \\
\hline 2001 & 105 & 134 & 176 \\
\hline 2000 & 101 & 146 & 336 \\
\hline 1999 & 61 & 67 & 91 \\
\hline 1998 & 3 & 9 & 5 \\
\hline 1997 & 28 & 102 & 99 \\
\hline 1996 & 65 & 30 & 188 \\
\hline 1995 & 24 & 41 & 51 \\
\hline 1994 & 5 & 1 & 6 \\
\hline 1992 & 4 & 33 & 0 \\
\hline 1991 & 7 & 21 & 60 \\
\hline 1990 & 3 & 12 & $\mathrm{O}$ \\
\hline
\end{tabular}

Sumber: www.wikipedia.org

Oleh karena, itu banyak film Hollywood yang mengasosikan Indonesia sebagai tempat berlangsungnya tindakan terorisme dan kejahatan lainnya. Seperti dalam Film Point Break (Keanu Reeves), The Condemned (2007), Java Heat, Serial Televisi "Alias", Serial TV, Commander In Chief (2006), Serial The West Wing, Film
The Kingdom, Film Proof Of Life, Serial TV Sleeper Cell (2005-2007), film Smallville (Serial TV, season 2, 2003), Film The Agency, dan serial The Unit (Season 1). 


\section{Penutup}

Berdasarkan temuan penelitian ini, Indonesia digambarkan sebagai negara yang aneh, kacau, dan tertinggal, sarang penjahat, tempat yang eksotis, terpencil, mistis dan misterius, tempat yang romantis dan tujuan berlibur, serta pusat teroris. Munculnya citra tersebut disebabkan oleh kurangnya pengetahuan orang Amerika tentang Indonesia yang disebabkan oleh distorsi media massa dan ketidakobyektifan para pembuat film Amerika dalam mencitrakan Indonesia.

\section{DAFTAR PUSTAKA}

\section{Buku}

Cipto, Bambang (2003). Tekanan Amerika Terhadap Indonesia: Kajian Atas Kebijakan Luar Negeri Clinton Terhadap Indonesia.. Yogyakarta: Pustaka Pelajar.

Elsaesser, Thomas and Buckland, Warren (2002). Studying Contemporary American Film: A Guide to Movie Analysis. London: Arnold.

Jacques, Aumont \& Marie, Michele. (1988). Film Analysis. London: Penguin

Motion Picture Association of America (2015). Theatrical Market Analysis. Los Angeles: MPAA

Ruffin, D. (2016). The Komedi Biooscop: The Emergence of Movie-Going in Colonial Indonesia, 1896-1914. Bloomington: Indiana University Press.

Said, Edward (1988). Orientalism. New York: Pantheon Books

\section{Internet}

Jakpat (2015). Survei Penonton Bioskop Indonesia. https://blog.jakpat.net/surveipenonton-bioskop-indonesia. Diakses pada 16 Agustus 2017

www.imdb.com

Wikipedia (2017. "List of terrorist incidents in Indonesia" dari https://en.wikipedia.org/wiki/List of terrorist incidents in Indonesi a. Diakses pada 25 Agustus 2017 